\title{
The Copper Inuit Soapstone Trade
}

\author{
DAVID MORRISON ${ }^{1}$
}

\author{
(Received 10 October 1990; accepted in revised form 15 January 1991)
}

\begin{abstract}
The existence of an important trade in soapstone vessels between Copper Inuit producers and the Inupiat of north Alaska during the 19th century is well known. This paper puts that trade firmly within the context of the Bering Strait intercontinental trade network, of which the Copper Inuit soapstone trade appears to represent the maximum geographic extent. Archaeological and documentary evidence suggests that it flourished for only about a generation, between about the 1840 s and the $1860 \mathrm{~s}$, before being circumvented by the Hudson's Bay Company and American trading interests in Alaska. The soapstone trade may have been the first step in the rise to relative prominence of the Kangiryuarmiut of western Victoria Island, one of two Copper Inuit groups that appear to have been directly involved.
\end{abstract}

Key words: Arctic, Inuit, Copper Inuit, history, archaeology, trade, soapstone

RÉSUMÉ. On connaît l'existence d'un important commerce de récipients de stéatite entre les producteurs Inuit du cuivre et les Inupiat de l'Alaska septentrional, au cours du XIX ${ }^{e}$ siècle. Cet article insère fermement ce commerce dans le contexte du réseau commercial intercontinental du détroit de Béring, dont le commerce de stéatite des Inuit du cuivre semble représenter l'extension géographique maximale. Des preuves archéologiques et documentaires suggèrent qu'il connut une période florissante durant seulement une génération, des années 40 environ aux années 60 du siècle dernier, avant de disparaître au profit de la Compagnie de la baie d'Hudson et des intérêts commerciaux américains en Alaska. Le commerce de la stéatite pourrait bien avoir été la première étape de l'accession à un certain statut pour les Kangiryuarmiut de l'ouest de l'île Victoria, l'un des deux groupes des Inuit du cuivre qui semblent avoir participé directement à ce commerce.

Mots clés: Arctique, Inuit, Inuit du cuivre, histoire, archéologie, commerce, stéatite

Traduit pour le journal par Nésida Loyer.

\section{INTRODUCTION}

The explorer Vihljalmur Stefansson once described an extensive native trade network stretching from Bering Strait to the country of the Copper Inuit and from thence to the Hudson Bay coast and beyond, to Baffinland and northwestern Greenland (Stefansson, 1914a). The most consistent staple of this trade was iron, mainly Siberian or Russian, with many local additions along the way (Siberian reindeer skins within Alaska, wood and copper in the central Arctic, etc.). Stefansson described in considerable detail the movement of a hypothetical Russian iron knife traded across Bering Strait in the early 18th century and how, within a minimum of two and a half years, it could pass from hand to hand all the way to the western coast of Hudson Bay ( $c f$. Simpson, 1875:267).

For Stefansson, this trade network was of major importance, providing a primary explanation for the comparative uniformity of Inuit material culture from northern Alaska to Greenland. "Knowing the continuity of trade routes between east and west, the rapidity of traffic, the readiness with which new ideas are adopted . . . may we not say that identity or similarity (e.g.) of needlecases in Smith sound [sic] and Alaska is as likely to be an evidence of the activity of commerce as of a common culture home and rockbound conservatism?"' (Stefansson, 1914a:8). The trade network was also probably very ancient, at least on the order of several centuries. Indeed, in some form at least, it existed "probably even in the earliest times"' (Stefansson, 1914a:4-5).

From a perspective of over 75 years, it is apparent that Stefansson greatly exaggerated the importance and unity of this trading network. The "mysterious Akilinik of the Greenlanders," for instance, is not a Greenlandic memory of the trading rendezvous of the same name on the Thelon River west of Hudson Bay (see Birket-Smith, 1929:30). Instead, it has a more local referent. To be fair, Stefansson wrote the article while on expedition at Cape Parry, without access to documentary sources or, of course, the fruits of more recent scholarship. And he does provide invaluable information on that portion of the trading network he knew best, in the area between northwestern Alaska and Coronation Gulf.

Among the chief items of this trade were soapstone lamps and pots. Soapstone is a raw material mainly associated with the Canadian Shield and is not generally found in the Western Arctic (Arnold and Stimmell, 1983; McCartney and Savelle, 1989). Vessels were quarried and manufactured by the Copper Inuit of the central Arctic, particularly in the Tree River area (see also Jenness, 1922:53-54, 1946:59). They were then traded west as complete vessels, because of the weight of the material.

Two routes appear to have been used (Fig. 1). One led across southern Victoria Island to Banks Island, where Kangiryuarmiut middlemen were met by Mackenzie Inuit from Cape Bathurst. This was said to be a wintertime trade, and the Mackenzie Inuit crossed to Banks Island over the sea ice from Cape Parry (Stefansson, 1914a:12). The second route led along the southern coast of Amundsen Gulf and seems to have been in the hands of the Akuliakattagmiut of Dolphin and Union Strait (see also Jenness, 1922:44). By the early 20th century, the Cape Parry route had apparently been forgotten by the Copper Inuit, while the Mackenzie Inuit had forgotten the mainland route. The importance of the latter has been questioned by Jenness (1922:45), who notes that strong currents off Cape Parry make wintertime travel there dangerous. From the Mackenzie Delta region, vessels were traded west via Barter Island and Nirlik (or "Nig'-a-lek"; Simpson, 1875:236), at the mouth of the Colville River, to distribution centres at Kotzebue Sound and Point Barrow.

At the time of effective European contact in the mid-19th century, most cooking pots and especially lamps from Kotzebue Sound to Cape Bathurst were made of Coronation Gulf soapstone rather than local pottery or stone (Armstrong, 1857:155; Murdoch, 1892:90, 105; Stefansson, 1914b:167; Spencer, 1959:55-56, 471; Savoie, 1970:165; Maguire,

\footnotetext{
${ }^{1}$ Archaeological Survey of Canada, Canadian Museum of Civilization, Hull, Quebec, Canada J8X 4H2

(C) The Arctic Institute of North America
} 


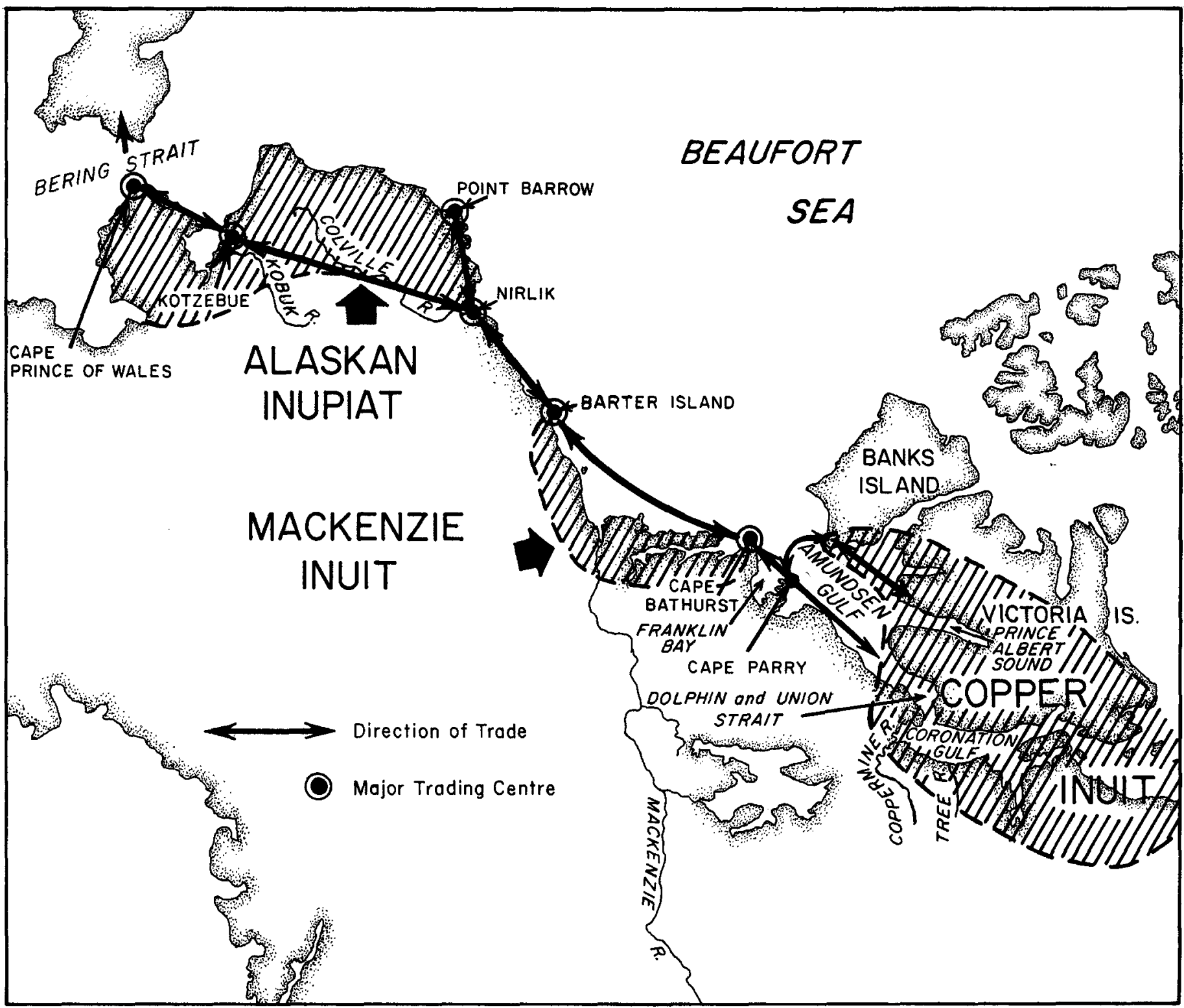

FIG. 1. Trade routes in Western and Central Arctic.

1988:114-115). They were commonly traded as far west as Bering Strait and Siberia (Nelson, 1983:63-65). Simpson (1875:269) reported that in the early 1850 s the geographic knowledge of the north Alaskan Inupiat extended east of the Mackenzie to a land "very distant . . . inhabited by the people who make the stone lamps." The identity of form (compare Murdoch, 1892:105, Fig. 47; Jenness, 1946:Fig. 51) and availability of the raw material make the Copper Inuit attribution for these vessels certain.

It seems clear that soapstone vessels were the most important western export of the Copper Inuit. Their only other scarce or valuable commodity was native copper, but the western copper trade appears to have been of comparatively minor significance. Copper is comparatively rare in Mackenzie Inuit sites (McGhee, 1974; Morrison, 1990), while the people of Cape Bathurst recalled that "pots and lamps were the chief objects of the trips across from the mainland at Parry" (Stefansson, 1914a:18). By at least the late 18th century, the desire for copper in the Western Arctic must have been slight, for the area was already being supplied with superior Russian metals. Indeed, it seems that Russian metal goods, particularly iron knives, were the chief items received by the Copper Inuit for their pots and lamps (Simpson, 1875:267; Jenness, 1922:44).

This paper examines the antiquity and economic context of the Copper Inuit soapstone trade from the perspectives of both archaeology and history. It concludes with observations on the possible social effects the trade may have had on the early Copper Inuit.

\section{THE ARCHAEOLOGY OF THE SOAPSTONE TRADE}

In the Eastern Arctic, the near-exclusive use of soapstone for lamps and cooking pots dates to the beginning of the Thule period, about 1000 years ago (Mathiassen, 1927). Evidently, Thule immigrants to the region quickly abandoned the pottery of their Alaskan ancestors in favour of the much more durable stoneware now widely available to them from a number of natural sources, so that pottery appears only rarely in the East. The Canadian Thule type-site of Naujan, 
for instance, produced only three pottery sherds, but several hundred soapstone vessel fragments (Mathiassen, 1927:63-66; Fig. 2).

This is not true, however, in the country of the Copper Inuit. Here, cultural connections with Alaska remained strong, and perhaps as a consequence pottery use continued unabated until the end of the Thule period at about A.D. 1400 or 1500 (Morrison, 1983). The Thule culture Clachan site on the western coast of Coronation Gulf, for instance, dates to about the same period as Naujan, or perhaps even later. Yet it presents a mirror image in terms of vessel material, with over 500 ceramic potsherds and only three soapstone vessel fragments, two of which had been reworked as scrapers (Morrison, 1983:151-159). This is despite the fact that the site is located within a few dozen kilometres of a recent soapstone quarry. High pottery frequencies occur in other local Thule sites, including Memorana (McGhee, 1972:36), Beulah (Morrison, 1983:192), and Lady Franklin Point (Taylor, 1972:35-37), again without any sign of soapstone. The pottery was similar to that used in northern Alaska at the time: a coarse-tempered, ill-fired, generally plain ware, usually in the form of situla-shaped pots or saucer-shaped lamps. The border dividing ceramic and a-ceramic Thule is poorly known, but there is reason to suspect that it lies toward the eastern end of Coronation Gulf, somewhere to the west of Cambridge Bay (William E. Taylor, pers. comm. 1990; see also Noice, in Taylor, 1972:4; Arnold and Stimmell, 1983:Fig. 8; McCartney and Savelle, 1989:Fig. 18).

The use of soapstone did not become common in the Coronation Gulf area until perhaps the 15th century. The Bloody Falls site (McGhee, 1972) appears to be the latest Thule culture site known in the area (Morrison, 1983:221-223); it produced soapstone and pottery in about equal quantities (McGhee, 1972:50-51). Pottery use as represented by single sherds seems to have continued very sporadically even into the 19th century (Morrison, 1981; Gordon, 1988), although by the ethnographic period the Copper Inuit used soapstone exclusively. It is uncertain why pottery was eventually abandoned after having been so favoured for several hundred years. However, it appears to be just one of several Eastern Arctic traits introduced into Coronation Gulf at the end of the Thule period (Morrison, 1983:278-279). However this may be, the Copper Inuit soapstone trade cannot be very old, because the Copper Inuit did not themselves begin to make and use soapstone vessels until terminal Thule times.

Looking west, beyond the area where soapstone is naturally available, it seems clear that the soapstone trade has almost no archaeological time depth whatever. Soapstone is absent and pottery relatively abundant ( 90 sherds) in Late Prehistoric houses at Iglulualuit, on the eastern fringe of the Mackenzie Delta area (Morrison, 1990:Table 7), and this observation is repeated in all but a very few prehistoric contexts farther west.

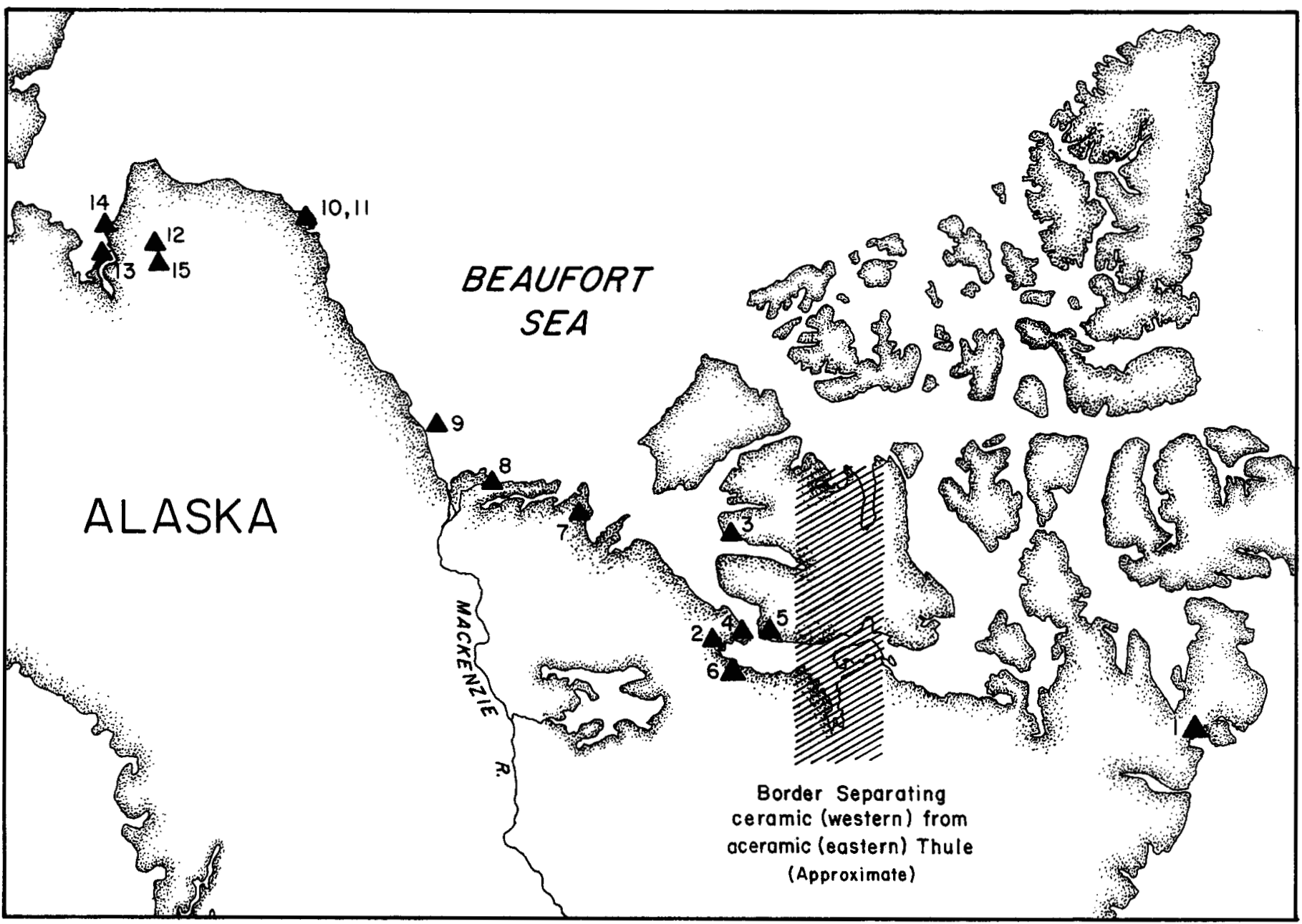

FIG. 2. Key to archaeological site locations: 1) Naujan, 2) Clachan, 3) Memorana, 4) Beulah, 5) Lady Franklin Point, 6) Bloody Falls, 7) Iglulualuit, 8) Kittigazuit, 9) Washout, 10) Walakpa, 11) Utkiavik, 12) Kangiguksuk, 13) Intermediate Kotzebue, 14) Krusenstern, 15) Ambler Island. 
For instance, Kittegazuit, in the Mackenzie Delta, produced 170 ceramic vessel sherds and only one soapstone fragment (McGhee, 1974:71-72). At Walakpa no soapstone was recovered, although Late Prehistoric levels yielded 211 pottery sherds (Stanford, 1976:57). Similarly, no soapstone has been reported from the Late Prehistoric Kotzuebue-culture components at Cape Krusenstern, although pottery was common and lamps were sometimes made of indigenous schist (Giddings and Anderson, 1986:44-48). The 16th-century Kangiguksuk site, on the Noatak River, and the 18th-century Ambler Island site, on the Kobuk River, likewise each produced 100 or more pottery sherds and no soapstone (Hall, 1971:43; Giddings, 1952:94).

A few Western Arctic sites have produced soapstone from apparently prehistoric contexts. Ford (1959:Table 15) recovered five soapstone vessel fragments from Late Prehistoric House $A$ at Utkiavik, four of them from above the roof. Thirtyfour ceramic sherds were in association. Yorga (1980:114) describes a soapstone pot fragment from MacNeish's (1956:50) excavations at the Thule culture Washout site on Herschel Island, again in apparent association with quantities of pottery ( 280 sherds). Finally, Giddings $(1952: 69,94)$ found a small fragment from the 16th-century Intermediate Kotzebue site on the Kobuk, along with 126 ceramic sherds. These few pieces, if not out of context, can do no more than suggest a very meagre and sporadic trade in soapstone prior to the well-attested historic trade. Indeed, writing of the Intermediate Kotzebue specimen, Giddings (1952:69) cautions that "we cannot assume a connection with the late spread of soapstone vessels from Canadian sources. Green soapstone is found occasionally as pebbles in Kobuk River gravels."

The regular and significant trade of soapstone lamps and pots appears to owe its existence to the rapidly changing trade relations of the Protohistoric and early Historic periods, and particularly to the expansion of an all-native trade network centred on Bering Strait.

\section{HISTORICAL CONTEXT}

The 19th-century soapstone trade as described by Stefansson and others can be seen as one of the outer ripples in a series of concentric trading circles. At the hub was Bering Strait and the Russian-Siberian fur trade. In 1649 the Russians established the Anadyrski post at the mouth of the Anadyr River in eastern Siberia (Ray, 1975:11). Although further Russian commercial and military expansion was greatly hampered from this point on by the active belligerence of the Chukchi, the presence of a Russian post and all it had to offer so close to Bering Strait must have had a major effect on the tiny intercontinental metal trade already in existence from prehistoric times (see McCartney, 1988). As early as 1742, Steller, of the Bering Expedition, described a wellorganized trade across Bering Strait, already several generations old and mainly in the hands of the Chukchi, who were trading Alaskan furs for Russian metal goods (Golder, 1968:98-99). By the late 1780s, some of this material was reaching the Mackenzie Delta area, along with reports of strange white men in large canoes (Lamb, 1970:208).

Two events that greatly increased the Bering Strait trade were the signing of a peace treaty between the Russians and the Chukchi in 1788 and the establishment of the Anyui fort and trade fair on the Kolyma River the following year (Ray, 1975:98-99). By its establishment, Anyui greatly increased the volume of Russian goods entering the New World through the offices of both Chukchi and Alaskan Inupiat middlemen. Russian trade goods now included tobacco as well as the staple beads and metal goods (knives, spear points, etc.), which were traded along with native Siberian articles such as spotted reindeer skins. In return, the Asian shore received local Alaskan products such as oil, ivory, and carved wooden implements, but it was above all furs in which the Russians were interested.

The Copper Inuit soapstone trade must be seen in the context of this Bering Strait-Alaskan trade network, since it was Russian iron that the Copper Inuit received for their goods. Moreover, their soapstone vessels were not merely useful domestic utensils, but valuable exchange items within the Alaskan network, and even across Bering Strait. Alaskan Inupiat greatly appreciated and valued Copper Inuit soapstone vessels, particularly the lamps, which, as Stefansson (1914a:27) notes, were felt to miraculously burn less oil than local imitations. However, they were in no position to regularly acquire eastern soapstone without a welldeveloped trade network and iron to give in exchange.

The large native Alaskan trade fairs at Cape Prince of Wales, Kotzebue, the Colville Delta, and Barter Island functioned as distribution centres within the context of this rapidly expanding Bering Strait trade. They did not even approach their historic scale of operation until the late 18th century (Ray, 1975:97-98). It seems that the Barter Island fair, providing the crucial link between Alaska and the Mackenzie Delta, did not begin until this time. In 1826, Mackenzie Inuit told Franklin that their trade with Alaskans at Barter Island had only begun within their own lifetimes (Franklin, 1971:130), while in the early 1850s Alaskan Inupiat told John Simpson (1875:268) that their trade at Barter Island was established "within the memory of people recently dead." Direct trade relations must have begun only a very few years before Mackenzie saw Russian iron in the Mackenzie Delta in 1789.

The expansion of trade into Coronation Gulf seems to date even later. Soapstone is mentioned and even stressed as an important trade item by John Simpson (1875) in the 1850 s and by most later writers. However, Franklin mentions only animal products and Russian goods traded between Mackenzie Inuit and Alaskans at Barter Island in 1826 (Franklin, 1971:130), and he further notes that while the Mackenzie Inuit had heard of people living around the mouth of the Coppermine River, "they were very far off, and .. . they had no intercourse with them"' (Franklin, 1971:203-204). Moreover, retrospective accounts describe trade between Copper Inuit and the Avvaqmiut of Cape Bathurst only, implying that the intervening coast was unoccupied (Stefansson, 1914a:12-13; Jenness, 1922:44). But Franklin Bay, immediately east of Cape Bathurst, supported a local population until about 1840 (Morrison, 1990), and these people would certainly have been involved had regular trade relations commenced while they still occupied the area.

A date as late as the 1840 s may seem surprising, but it is not directly contradicted by any of the few early historic accounts. Beechey collected a toy soapstone lamp of apparent Copper Inuit provenance from Kotzebue Sound in 1826 (Bockstoce, 1977:Fig. 70), but it is unique. Like the few prehistoric soapstone sherds from archaeological contexts, it need indicate no more than a very meagre and sporadic trade at this date. Otherwise, Beechey describes only "earthen jars for cooking" (Beechey, 1831:[I]:409, [II]:372, 377). 
Richardson, also in the 1820 s, mentions signs of Inuit travelling parties along the Amundsen Gulf coast (in Franklin, 1971:241, 246), but there is again no evidence that these were trading parties. He also describes lamps made of "potstone" used by the Copper Inuit but fails to describe what Mackenzie Inuit lamps of the same period were made of (Franklin, 1971:216, 249). Indeed, as late as 1837, Thomas Simpson (1843:177) could describe trade between Mackenzie Inuit and north Alaskans without mentioning soapstone, although he later describes "lamps and dishes hollowed out of a soft grey stone" used by Copper Inuit (Simpson, 1843:264, 273).

\section{CHANGING TRADE RELATIONS}

The Copper Inuit soapstone trade came to an end sometime early in the second half of the 19th century. We know from John Simpson's (1875) account that it was thriving in the early 1850 s. By the 1880 s, Murdoch reports that soapstone pots had been entirely out of use at Point Barrow for some time, and lamps, while still sometimes used, were all apparently heirlooms (Murdoch, 1892:90, 105). In a similar vein, Jenness's Copper Inuit informants described the cessation of trade relations with the West at least two generations prior to 1915 (Jenness, 1922:44-45). The Copper Inuit soapstone trade probably marks the high-water mark of the Bering Strait trade network, and it appears to have flourished for only a single generation, from perhaps the 1840 s to the 1860 s.

The end of the soapstone trade is one of the earliest indications that the all-native Bering Strait trade network was being circumvented by (primarily) American and British traders. Two important events in this process include the first establishment of direct sustained trading between American whalers and traders and Alaskan Inupiat and between the Hudson's Bay Company and Mackenzie Inuit, both in the 1850s (Bockstoce, 1986:180-204; McGhee, 1974:2-4). Throughout the Western Arctic, soapstone vessels appear to have been rapidly supplanted by metal pots, kettles, meat tins, and frying pans (which sometimes served as lamps) (Murdoch, 1892:90; MacFarlane, 1891:35; Ray, 1975:243; Maguire, 1988:97), and trade routes between the Mackenzie and Copper Inuit were quickly abandoned. Alaskan native trade fairs continued and even prospered for several decades after mid-century, stimulated by the easy availability of European and Euro-American goods. But with the continued expansion of direct trade they more and more became local phenomena and finally disappeared altogether (Oswalt, 1967:132-133).

Still living beyond the orbit of direct trade and now cut off from native trade with the West, the Copper Inuit turned elsewhere for their iron. One important source was the Akilinik or Thelon River route to the southeast, bringing Copper Inuit in contact with Caribou Inuit, and ultimately with trade goods from the Hudson's Bay Company and the American and British Hudson Bay whaling fleets. In one form or another, this trade route appears to date from at least the 1820s (see Franklin, 1969:264-265) and was the most important source of European trade goods in the early 20th century (Jenness, 1922:48; see also Birket-Smith, 1929:162163). In return for these goods, the Copper Inuit exchanged not soapstone, easily available west of Hudson Bay, but the skins of caribou, muskoxen, and fox.

A more providential and probably even more valuable source of both wood and European metal was M'Clure's ship HMS
Investigator, abandoned off the northern end of Banks Island in 1853. It was found within a few years by Copper Inuit hunters of the Kangiryuarmiut group and systematically scavenged for several decades (Stefansson, 1914b:38-39; Hickey, 1984). Its finding must have greatly dampened any Copper Inuit motivation to trade soapstone for more distant metals.

\section{EFFECTS OF THE SOAPSTONE TRADE ON THE COPPER INUIT}

Although the existence of the Copper Inuit soapstone trade is well known, it is striking how little direct historical information there is on it. This is particularly true of the Copper Inuit end of the network, for they remained essentially unknown to the outside world throughout the 19th century, despite the occasional brief visit by the British Royal Navy. Victoria Island, for instance, was widely considered uninhabited as late as 1906 (Stefansson, 1913:4). John Simpson is the only significant witness to the soapstone trade while it was a reality in the $1850 \mathrm{~s}$, and he only observed the western end of the trade, between Mackenzie Inuit and Alaskan Inupiat. There are no contemporary witnesses to the Copper Inuit end of the trade, and by the time they were visited by Jenness and Stefansson in the early 20th century even its memory seems to have begun to fade. This is perhaps not surprising when we consider that the soapstone trade seems to have had a duration of only a single generation. Clearly, Stefansson was wrong in assigning it any real antiquity.

One fairly certain effect of the soapstone trade is the importation of some quantity of Russian iron into Copper Inuit society in the form of knives and possibly other edged tools. Iron knives are the only item specifically mentioned in either first-hand or retrospective accounts (Simpson, 1875:267; Stefansson, 1914a:5-6; Jenness, 1922:45), and it seems certain that the aboriginal tobacco trade did not extend east of Cape Bathurst.

No Russian trade material has yet been identified in ethnographic or archaeological collections from the Copper Inuit. Indeed, few collections date to the right period. Aside from Banks Island sites associated with the Investigator (Hickey, 1984), only two controlled archaeological collections can be confidently ascribed to the 19th-century Copper Inuit, but both date mainly to the latter half of the century. They include significant quantities of European or Euro-Canadian metal, but this has been ascribed to the scavenging of the Investigator, rather than to a Russian source (McGhee, 1972:71-100; Morrison, 1981:262). A few other very small, possibly Protohistoric, sites (McGhee, 1972:58-67; Morrison, 1981:261) also include a few scraps of European metal, but nothing that could be identified as a Russian knife. Ethnographic collections made by Stefansson, Jenness, and others early in this century may be too late to be relevant. Any Russian metal blades they might include would presumably have been reworked and rehafted (see Jenness, 1946:97) and would be very difficult to identify, particularly since there was nothing very remarkable about them to begin with ("crudely forged and double edged": Maguire, 1988:78; see also Murdoch, 1892:156). Small ethnographic collections made in the mid-19th century by Collinson, M'Clure, and Richardson might be promising, although it is unlikely that an iron knife is something an Inuk of the day would have parted with voluntarily. These collections have not been described and, being housed in British museums, are not readily available to North American scholars. 
The quantities of iron involved were probably not great but could still have had a significant impact on Copper Inuit society. Hickey (1984) has proposed a model of social change among the Copper Inuit during the late 19th century that can serve as a basis of discussion. Focusing on iron and other materials scavenged from the Investigator, he argues that the injection of large quantities of such "wealth" into Copper Inuit society may have threatened its egalitarian basis, since the "producers" of wealth were comparatively few. To maintain exchange parity between those with direct access to the Investigator (i.e., the Kangiryuarmiut) and those without such access, he suggests that the production of traditionally valuable goods may have been intensified by "havenot" individuals, resulting in a number of significant changes to Copper Inuit society.

Hickey's suggestions are of considerable interest, since they tend to undermine the perception that Copper Inuit society was uniquely pristine and untouched by outside contact at the time of ethnographic description early in this century. They also advance an example of "uneconomic" behaviour on the part of "have" individuals, who were apparently willing to forego the social and economic advantages of their situation because of the extreme value placed on egalitarianism. For exchange parity could only be maintained if the "haves" limit their "having" to Investigator goods and did not attempt to compete with "have-nots" in the acquisition of other valuable materials at the same time. Nonacquisitive, non-competitive behaviour of this sort may not be unique, but it is still rare enough that another example would be heartening to any student of human behaviour.

There is reason, however, to doubt Hickey's model, both with respect to the Investigator and as possibly applied to the earlier introduction of Russian metals in the 1840s and '50s. Chief among traditional goods whose use should have been intensified is native copper; indeed it is the only one that can be directly investigated. And, in fact, there is no evidence that the use of copper increased during the 19th century. Copper is about as abundant in local Thule-period sites as are all metals on late-19th-century sites, suggesting instead the slow substitution of iron (Morrison, 1987).

Rather than resulting in a successful struggle to maintain exchange parity, differential access to foreign wealth may actually have increased competitiveness, at least on the intergroup level. At contact, the Copper Inuit were divided into a number of relatively fluid and probably comparatively short-lived local territorial groups (Damas, 1984). None was large enough to constitute an independent deme, or marriage universe, and some were as small as twenty people (Stefansson, 1914b:27). In 1910, Stefansson (1914b) counted 18 such groups among the Copper Inuit; by 1915 this number appears to have decreased to 16 (Jenness, 1922:33-44). What documentary evidence there is suggests limited but real competition among them over access to foreign wealth, with resulting fluctuations in size and relative prestige.

In the late 18 th and early 19 th centuries, at the very beginning of the period that concerns us here, the best known and evidently the most important Copper Inuit territorial group was the Nagyuktogmiut, or "Deer Horn Esquimaux." The name was first recorded in 1821, when Franklin described them ("Nagge-ook-tor-moeoot") living near the mouth of the Coppermine River. According to an informant, they usually frequented Bloody Falls during the summer "for purposes of salting salmon" and then wintered near
Richardson River a few dozen kilometres to the west (Franklin, 1969:352-353). It was presumably Nagyuktogmiut whom Samuel Hearne's Chipewyan guides slaughtered in the famous massacre at Bloody Falls in July 1771 (Hearne, 1958:96-103). They may also have been the first Copper Inuit to receive European iron, a few pieces of which were noted by Hearne in their plundered gear (1958:110). The source of this iron was almost certainly the Hudson's Bay Company post at Fort Prince of Wales (Churchill), and it was probably among items traded or presented by the Chipewyan traders Matonabbee and Idotleaza in the late 1760s (Hearne, 1958:224 fn). Presumably the Bloody Falls massacre put an end to this tenuous relationship.

Whatever the source of their preeminence, the Nagyuktogmiut were certainly the best-known Copper Inuit group during the 19th century. In 1826, on his second expedition, Franklin met Mackenzie Inuit near Kittigazuit who had heard of their countrymen at the mouth of the Coppermine River and "knew them by their name of Naggoe-ook-tor-moe-oot (or Deer-horns)" (Franklin, 1971:203). Other Mackenzie Inuit informants from Cape Bathurst told Stefansson (1913:159) early in the 20th century that the Nagyuktogmiut were socalled because they fought for their wives with caribou antlers. Furthermore, "They also kill all strangers." Evidently, the Mackenzie Inuit used the term as a general reference to all Copper Inuit, despite the fact that by the early 20 th century the Nagyuktogmiut were a small, remote, and comparatively unimportant group occupying the southern coast of Victoria Island (Stefansson, 1914b:31; Jenness, 1922:37).

Over the course of the 19th century the prestige and importance of the Nagyuktogmiut may have been eclipsed by that of the Kangiryuarmiut of the Prince Albert Sound region of western Victoria Island. In 1911, Stefansson (1913:293-294, 1914a, 1914b:29-31, 36-37, 113) described the Kangiryuarmiut as one of the largest Copper Inuit groups, numbering about 200 people, as compared with fewer than 50 Nagyuktogmiut. They had the richest hunting grounds and were among the best travelled and the most actively involved in trade, including the Akilinik trade. They also appear to have been the best supplied with metals, both European metal from the Investigator, of which they were the chief " "producers," and native copper. Stefansson comments that "of all the tribes whom we visited, the Kanhiryuarmiut [his spelling of Kangiryuarmiut] are paramountly the makers of weapons and implements of copper" (Stefansson, 1914b:113). Indeed, "From the point of view of what an Eskimo wants and needs, ... . the Kanhiryuarmiut had natural resources within the limits of their annual migrations as a tribe, which must formerly, even more than now, have made them nearly or quite the most prosperous tribe of the district we are considering"' (Stefansson, 1914a:16).

Jenness (1922:41) paints a slightly less rosy picture, detailing reports of famines and other natural disasters that had reduced the Kangiryuarmiut population considerably within recent memory (see also Stefansson, 1913:288-290). He also reports that they were relatively unimportant economically; their most valuable commodity within the close network of Copper Inuit trade was polar bear hide, not copper. Indeed, "it would seem that the Coppermine valley, rather than either Victoria island or Bathurst inlet, was always the main source of the supply of this metal"' (Jenness, 1922:52).

How are we to reconcile these two descriptions? Several preliminary comments can be made. One is that Jenness never 
visited the Kangiryuarmiut on their own ground, although he did briefly meet a small party that came to trade with his Puivlik hosts (Jenness, 1922:41, 51). Stefansson, on the other hand, knew them comparatively well (Stefansson, 1913:279-301). They may even have been among his "Blond Eskimo," whom Stefansson very dubiously suggested were descendants of the lost Norse Greenlandic colony (1913:190-202).

Rather than relating the discrepancy to comparative ignorance on one hand and excessive enthusiasm on the other, however, a key can be sought in chronology. As Jenness (1922:52) states, "Economically these northern Eskimos are of little importance to their southern neighbours, at least at the present day" (emphasis added). Similarly, Stefansson, as quoted above, mentions that the prosperity of the Kangiryuarmiut was greatest "formerly, even more than now." It seems likely that the economic importance of the Kangiryuarmiut had declined considerably from the late 19th century, and even between 1911, when they were visited by Stefansson, and 1915, when Jenness did his study. This may explain the high population figures given for the Kangiryuarmiut both by Stefansson and Jenness (1922:41) even for the early 20 th century. In the late 19 th century, the Kangiryuarmiut were said to have been "much more numerous" (Jenness, 1922:41), yet they evidently lived in a territory where hunting was comparatively unreliable and starvation relatively common. Stefansson appears to have been incorrect in suggesting that the Kangiryuarmiut had particularly rich hunting grounds. The opportunities for acquiring non-food resources may have attracted a larger population than could be sustained in the long term.

As for copper, however wide its natural availability, it does seem that the Kangiryuarmiut specialized in manufacturing and using copper tools. Certain kinds of tools, such as harpoon foreshafts or seal-hole probes, for instance, were sometimes made of copper by the Kangiryuarmiut but invariably of wood or antler by other Copper Inuit (Stefansson, 1913:294, 1914a:17; see also Jenness, 1946:115). Certainly it was copper that most impressed their first outside visitors. Captain M'Clure, of HMS Investigator, met Kangiryuarmiut (or possibly the closely allied Kanghiruatjiagmiut) on western Victoria Island in 1851, two years before the Investigator was abandoned. He commented that "copper of the purest description seemed to be plentiful with them, for all their implements were of that metal" (M'Clure, 1969:188). Other members of his crew made similar observations (Armstrong, 1857:339; Miertsching, 1967:115). Jenness may not in fact be the best judge of the early importance of copper among Kangiryuarmiut, for by the time of his visit, as he notes, "hardly a single copper-bladed knife remained in the country" (Jenness, 1946:98). He further cautions, "It must be remembered . . . that iron has largely superseded copper during the last ten or fifteen years, and that while the softer metal alone was procurable the deposits at the head of Prince Albert sound must have been far more important economically than they are now" (Jenness, 1922:52).

Reasons for a decline in Kangiryuarmiut fortunes are easily suggested. The Investigator was no longer available as a source of exotic materials after about 1890 (Hickey, 1984:19). By at least 1905, and especially after 1911, all Copper Inuit trade was massively affected by direct trade with American trading vessels sailing from Alaska and Herschel Island. Men like captains Mogg, Klengenberg, and Bernard in effect outflanked the Kangiryuarmiut (see Jenness, 1922:31; Bockstoce, 1975), destroying the old copper culture and undermining the value of more distant metal sources.

The original basis of the comparative wealth and importance of the 19th-century Kangiryuarmiut may have been the soapstone trade. As we have seen, the Kangiryuarmiut were one of two groups directly involved in interregional trade with the West. Perhaps initially unimportant, it was still a harbinger of things to come. When the soapstone trade ended in the 1860 s, the Kangiryuarmiut seem to have been able to consolidate and probably even better their trade position through the fortuitous discovery and scavenging of the abandoned Investigator. As Stefansson (1914a:17) put it in relation to the copper trade, the scavenging of the Investigator "helped the tribe retain the mastery of the commercial situation locally."

The fact that the Kangiryuarmiut were also actively engaged in the manufacture of native copper goods throughout this period seems to contradict Hickey's model of "balanced" egalitarianism. Their active involvement in the Akilinik trade, despite their geographic remoteness, can be seen in a similar light. Even if "poorer" groups did intensify production in an attempt to keep up with the newly wealthy (and there is no compelling evidence they did), the latter do not appear to have cooperated by limiting their competitiveness in other spheres.

The effects of foreign wealth on the 19th-century Copper Inuit were probably not profound, except perhaps within the limited realm of material technology. Access to Russian knives and British iron does appear to have affected the relative size and prestige of territorial groups. There is no evidence, however, that the egalitarian basis of Copper Inuit society was ever seriously threatened by the kinds of economic opportunities represented by a Russian knife, or even a sledge load of scavenged wood and iron scrap. Membership within specific local groups was always comparatively fluid, allowing potentially wide direct access to scarce resources. Nor were the Kangiryuarmiut the only group "controlling" exotic materials, for there was always the Akilinik trade. Finally, even with abundant iron, the Copper Inuit continued to live in one of the most fiercely limiting environments in the Arctic. Access to food and cooperation regarding its acquisition and sharing must have remained the primary constraints on social change.

\section{REFERENCES}

ARMSTRONG, A. 1857. A personal narrative of the discovery of the northwest passage. London: Hurst and Blackett.

ARNOLD, C., and STIMMELL, C. 1983. An analysis of Thule pottery. Canadian Journal of Archaeology 7(1):1-22.

BEECHEY, F.W. 1831. Narrative of a voyage to the Pacific and Beering's Strait. 2 vols. London: $H$. Colburn and Richard Bentley.

BIRKET-SMITH, K. 1929. The Caribou Eskimos. Report of the Fifth Thule Expedition 1921-24, 5(1):1-306.

BOCKSTOCE, J. 1975. Contacts between American whalemen and the Copper Eskimos. Arctic 28(4):298.

1977. Eskimos of northwest Alaska in the early nineteenth century. University of Oxford, Pitt Rivers Museum, Monograph Series I. 1986. Whales, ice, \& men: The history of whaling in the Western Arctic. Seattle: University of Washington Press.

DAMAS, D. 1984. Copper Eskimo. In: Damas, D., ed. Handbook of North American Indians. Vol. 5: Arctic. Washington, D.C.: Smithsonian Institution. 397-414. 
FORD, J. 1959. Eskimo prehistory in the vicinity of Pt. Barrow, Alaska. Anthropological Papers of the American Museum of Natural History 47(1):1-244.

FRANKLIN, J. 1969. Narrative of a journey to the shores of the Polar Sea, in the years 1819, 20, 21, and 22. New York: Greenwood Press. Originally published 1823.

1971. Narrative of a second expedition to the shores of the Polar Sea in the years 1825, 1826, and 1827. Rutland, Vermont: Charles Tuttle. Originally published 1828 .

GIDDINGS, J.L. 1952. The arctic woodland culture of the Kobuk River. University of Pennsylvania, University Museum Monograph 8:1-143.

GIDDINGS, J.L., and ANDERSON, D. 1986. Beach Ridge archaeology of Cape Krusenstern. U.S. Department of the Interior, National Parks Service, Publications in Archaeology 20:1-386.

GOLDER, F.A. 1968. Bering's voyages. Vol. II: Steller's journal of the sea voyage from Kamchatka to America and return on the second expedition, 1741-1742. New York: Octagon Books.

GORDON, B. 1988. Nadlok and its unusual antler dwellings. Arctic 41(2):160-161.

HALL, E. 1971. Kangiguksuk: A cultural reconstruction of a sixteenth century Eskimo site in northern Alaska. Arctic Anthropology 8(1):1-101.

HEARNE, S. 1958. A journey to the Northern Ocean. Toronto: Macmillan.

HICKEY, C. 1984. An examination of processes of cultural change among nineteenth century Copper Inuit. Etudes/Inuit/Studies 8(1):13-35.

JENNESS, D. 1922. The life of the Copper Eskimos. Report of the Canadian Arctic Expedition, 1913-18, 12(a):1-277.

1946. Material culture of the Copper Eskimo. Report of the Canadian Arctic Expedition, 1913-18, 16:1-148.

LAMB, W.K., ed. 1970. The journals and letters of Sir Alexander Mackenzie. Toronto: Macmillan.

MacFARLANE, R. 1891. On an expedition down the Begh-ula or Anderson River. The Canadian Record of Science 4:28-53.

MACNEISH, R, 1956. Archaeological reconnaissance of the delta of the Mackenzie River and Yukon coast. National Museum of Canada Bulletin 142:46-81.

MAGUIRE, R. 1988. The journal of Rochfort Maguire 1852-1854. London: Hakluyt Society.

MATHIASSEN, T. 1927. Archaeology of the Central Eskimos. Report of the Fifth Thule Expedition 1921-24, 4(1):1-327.

MCCARTNEY, A. 1988. Late prehistoric metal use in the New World Arctic. In: Shaw, R., Harritt, R., and Dumond, D., eds. The late prehistoric development of Alaska's native people. Alaska Anthropological Association Monograph Series 4:57-80.

MCCARTNEY, A., and SAVELLE, J. 1989. A Thule Eskimo stone vessel complex. Canadian Journal of Archaeology 13:21-50.

MCGHEE, R. 1972. Copper Eskimo prehistory. National Museum of Man, Publications in Archaeology 2:1-139.
1974. Beluga hunters. Memorial University of Newfoundland, Newfoundland Social and Economic Studies 13:1-124.

M'CLURE, R. 1969. The discovery of the North-West Passage. Edmonton: Hurtig.

MIERTSCHING, J. 1967. Frozen ships: The arctic diary of Johann Miertsching. Toronto: Macmillan.

MORRISON, D. 1981. A preliminary statement on Neo-Eskimo occupations in western Coronation Gulf, NWT. Arctic 34(3):261-269.

1983. Thule culture in western Coronation Gulf, N.W.T. National Museum of Man, Mercury Series, Archaeological Survey of Canada Paper 116:1-365.

1987. Thule and historic copper use in the Copper Inuit area. American Antiquity 52(1):3-12.

1990. Iglulualumiut prehistory: The lost Inuit of Franklin Bay. Canadian Museum of Civilization, Mercury Series, Archaeological Survey of Canada Paper 142:1-201.

MURDOCH, J. 1892. Ethnological results of the Point Barrow Expedition. Ninth Annual Report of the Bureau of American Ethnology.

NELSON, E. 1983. The Eskimo about Bering Strait. Washington, D.C.: Smithsonian Institution. Originally published 1899.

OSWALT, W. 1967. Alaskan Eskimos. Scranton, Pa.: Chandler.

RAY, D.J. 1975. The Eskimos of Bering Strait, 1650-1898. Seattle: University of Washington Press.

SAVOIE, D., ed. 1970. The Amerindians of the Canadian Northwest in the 19th century, as seen by Emile Petitot. Vol. 1: The Tchiglit Eskimos. Mackenzie Delta Research Project 9:1-228.

SIMPSON, J. 1875. The Western Eskimo. In: Markham, C., ed. A selection of papers on arctic geography and ethnology. London: J. Murray. 233-275.

SIMPSON, T. 1843. Narrative of discoveries on the north coast of America. London: R. Bentley.

SPENCER, R. 1959. The North Alaskan Eskimo: A study in ecology and society. Bureau of American Ethnology Bulletin 177:1-490.

STANFORD, D. 1976. The Walakpa Site, Alaska. Smithsonian Contributions to Anthropology 20:1-226.

STEFANSSON, V. 1913. My life with the Eskimo. New York: Macmillan. 1914a. Prehistoric and present commerce among the arctic coast Eskimo. Geological Survey of Canada, Museum Bulletin 6:1-29. 1914b. The Stefansson-Anderson Arctic Expedition: Preliminary ethnological results. Anthropological Papers of the American Museum of Natural History 14(1):1-395.

TAYLOR, W. 1972. An archaeological survey between Cape Parry and Cambridge Bay, N.W.T., Canada in 1963. National Museum of Man, Mercury Series, Archaeological Survey of Canada Paper 1:1-105.

YORGA, B. 1980. Washout: A western Thule site on Herschel Island, Yukon Territory. National Museum of Man, Mercury Series, Archaeological Survey of Canada Paper 98:1-201. 